\title{
Industrial Practice for Reducing Defective Sterile Milk Products Produced Using Overpressure Rotary Retorts
}

\author{
Muhamad Wahyu Pamuji ${ }^{a}$, Eko Hari Purnomo ${ }^{a}$, And Azis Boing Sitangganga \\ ${ }^{a}$ Department of Food Science and Technology, IPB University, Jalan Raya Dramaga Kampus IPB Dramaga \\ Bogor 16680, West Java, Indonesia \\ ${ }^{*}$ Corresponding author \\ h.purnomo@apps.ipb.ac.id \\ TEL.: +62-251-8626725
}

Received: 6 March 2020; Published online: 18 April 2021

\begin{abstract}
Indonesian consumers are fond of commercially sterilized milk as indicated by increasing product sales. High demand for products intensifies the need to increase productivity, generally achieved by minimizing product defects. This study aimed to reduce the number of defects in commercially sterilized milk produced using overpressure rotary retorts. Based on Pareto analysis, the percentage of defective products was $5.14 \%$ of which $2.37 \%$ were dented bottles. A cause-effect diagram (Ishikawa Diagram) was used to find the root cause of dented bottles. The pressure difference between the retort chamber (external pressure) and inside the product packaging (internal pressure), and the number of bottles stacked inside the retort basket (bottle density) were found as major factors for causing dented bottles. The internal pressure was 1.20 bar higher than the external pressure. By reducing the pressure difference to $0.40 \mathrm{bar}$, the percentage of dented bottles could be reduced to $0.79 \%$. Applying the lowest bottle density ( $73 \%$ of the retort basket area occupied by bottles) during the sterilization process could decrease the number of dented bottles, however, it also increased the appearance of striped lids. The best conditions for sterilization (pressure difference $=0.40$ bar; number of bottles $/$ basket $=1938$ bottles) which were used in the three-month full-scale production trial reduced the percentage of defective products from $5.14 \%$ to $2.24 \%$ of which $0.76 \%$ were dented bottles. Setting the retort pressure at 2.80 bar could avoid 52,920 defective bottles of commercially sterilized products per month.
\end{abstract}

Keywords: Commercially sterilized milk; Product defects; Dented bottles; Overpressure rotary retorts; Sterilization

\section{Introduction}

Based on the Neilsen RMS $1^{\text {st }}$ quarter of 2019 Survey in Indonesia, consumption of liquid and powder milk increased by $11 \%$ and $5 \%$, respectively. Increased consumption of liquid milk in Indonesia makes competition among producers even tighter. To remain competitive notably requires continuous innovation and cost reduction strategies during the production of dairy-based products (Kong, Yang \& Xu, 2019; Magnus- son \& Berggren, 2017). In terms of improving a product's quality and productivity, reducing product defects may be considered as a strategy (Zhang, Kano, Tani, Mori \& Harada, 2018).

According to Ahmad and Ginantaka (2018), product defect categories in commercially sterilized bottled milk are leak, blown, nonstandard label, no coding, dented bottle, narrow seal, folded, wrinkle and overheat. The bottle used for commercially sterilized milk is mostly made of HDPE (high-density polyethylene) (Potts, Amin 
\& Duncan, 2017). As an elastic material, HDPE bottles will expand when exposed to heat (Zheng, Zhang, Ma, Wang \& Yu, 2019). Balancing the internal and external pressure of the packaging during the sterilization process is important to prevent deformation defects in semi-flexible packaging (Hariyadi, 2017). Primanintyo, Syafei and Luviyanti (2016) reported a successful application of the six sigma method to reduce defects in the production of car tyres. A similar approach to decrease product defects in the textile industry (Heijacker company) was also reported by Wulandari and Bernik (2018). These studies indicated that product defects could be reduced by up to $50 \%$. This study aims to reduce the number of defective commercially sterilized milk products in HDPE bottle produced using overpressure rotary retorts.

\section{Materials and Methods}

\section{$2.1 \quad$ Materials}

High-density polyethylene (HDPE) bottles (volume of $140 \mathrm{~mL}$ ) produced by Kalbe Milko Indonesia Company were used in this research. Commercially sterilized milk was produced according to the standard operating procedures (SOP) of the company. The sterilization process was carried out using a Stock DFT Rickerman SRX 1300-4-HV-PS overpressure rotary retort (Germany) equipped with PicoVACQ Orion TMI $1 \mathrm{C}$ data logger (France) and an Ellab Track Sense Pro - Wireless Data Logger (Denmark). Statistical data analysis was carried out by Minitab 19 (United States).

\subsection{Methods}

\section{Pareto Analysis}

Data used for Pareto analysis was from the production period of March 2018-February 2019 at the Kalbe Milko Indonesia Company. The defect categories and number of defects were collected during this period. Based on the Pareto analysis, the defect category with the highest percentage of all defects was further investigated and discussed within this study.

\section{Cause-effect Analysis for the Selected Product Defect Category}

An Ishikawa (fishbone) diagram was used to investigate the selected product defect category. Factors causing the defect in the selected product defect category were analyzed through discussions with machine suppliers and production, engineering and utilities unit staff in the company. The cause-effect analysis covered four aspects: man, method, machine and material. The possible root causes of each aspect were determined by focus group discussions.

\section{Improvement of the Largest Defect Category}

Possible root causes obtained from the causeeffect analysis were mitigated and implemented during production. During the production trial, the heat adequacy of the sterilization process was measured in terms of minimum $\mathrm{F}_{0}$ value. The $\mathrm{F}_{0}$ value was determined using the trapezoidal method, based on dynamic product temperatures recorded by the data logger (Ellab Track Sense Pro Wireless Data Logger).

\section{Verification of Improvement in Results}

A 3-month production trial was carried out to verify the improvement. The improvement was quantified by comparing data from the 3-month production trial and the production for one year prior to this study covering the number of product defects in all identified defect categories.

\section{Results and Discussion}

\subsection{Pareto Analysis of Product Defects}

Pareto analysis is used to analyze a series of processes that aim to overcome weaknesses or problems that arise (Wang \& Choi, 2019). Pareto analysis focuses on risk that might occur when designing and modifying a process. The Pareto analysis principle lies in determination of the $20 \%$ of main causes that must be dealt with so 
as to solve $80 \%$ of the problems. Absolute values can be arranged in Pareto diagrams to show which technical characteristics are the most important and the risk priorities of existing requirements (Erdil, 2019). Pareto analysis is also used to prioritize determinants that can be a focus for improvement (Shivajee, Singh \& Rastogi, 2019). Pareto diagrams of defective products from March 2018 to February 2019 are shown in Figure 1. The largest contributor to total product defects was dented bottles $(2.37 \%)$. Total product defects were $5.14 \%$ of the total production. Therefore, dented bottles contributed $46.07 \%$ of the total product defects. In this study, the dented bottle defect category became the priority for improvement to identify the root cause through fishbone diagram analysis.

\subsection{Cause-effect Analysis for the Largest Product Defect Category}

Dented bottles were observed to occur during the sterilization production process. The determination of cause-effect in the Ishikawa's diagram is unlimited but it can be used to determine significant factors (Simanova \& Gejdos, 2015). Fishbone diagrams require a focus group discussion as the main tool to identify the main problem (Elleuch, Dafaoui, El Mhamedi \& Chabchoub, 2016). Through discussions with machine suppliers, production teams, engineering teams and the utility team, the main causes of the problem for each factor were found. The cause-effect analysis results are shown in Figure 2.

\section{Man}

The man factor in the cause-effect analysis is the operator who operates the retort. Retort operators' technical knowledge, technical skills and technical behavior were evaluated by experts from the machine supplier. Each production shift had one operator of the retort and there were three shifts in one day. Every year, the supplier provides refresher training for the operators and assesses their competencies. An evaluation of operators' competencies was based on pre-test and post-test results, with a minimum pass score of
8.0. Based on Table 1, the technical knowledge, technical skills and technical behavior of the operators meet the supplier's standards. Therefore, the retort operator is not the cause of dented bottles.

Table 1: Pretest and posttest scores for retort operators trained by the machine supplier.

\begin{tabular}{lccc}
\hline Operator & Pretest & Posttest & Note \\
\hline Operator A & 8.0 & 10.0 & Pass \\
Operator B & 8.5 & 9.5 & Pass \\
Operator C & 8.0 & 9.5 & Pass \\
\hline
\end{tabular}

\section{Machine}

Closed containers of the food to be sterilized are placed in the retort for a certain time, at high temperature and pressure. A commonly used material of containers in a retort process is HDPE (High-Density Polyethylene) plastic. The sterilization process used with semi-flexible packaging requires over pressure to maintain the integrity of the packaging. Packaging damage can occur due to an improper combination of increased pressure and expansion of the product in the containers (Augusto, Tribst \& Cristianini, 2014). The sterilization process parameters that must be controled are temperature, time, pressure and temperature distribution in the retort (Hariyadi, 2017). The retort supplier ensures the good working condition of the retort through a retort maintenance agreement. The supplier's annual retort inspection report in June 2018 showed that the retorts were in good condition and working properly. A reading from the retort thermometer was within the tolerance limit based on the calibration results. The retort thermometer calibration was performed at temperatures between $100.00{ }^{\circ} \mathrm{C}$ and $122.00{ }^{\circ} \mathrm{C}$, with a maximum correction of $+0.1597{ }^{\circ} \mathrm{C}$ which is below the maximum correction required by the maker $\left( \pm 0.5000{ }^{\circ} \mathrm{C}\right)$. Other checks were carried out on the timer used in the retort, the pressure gauge of the retort, the rotary speed of the basket and the sterilization value obtained by the products. Checks on the timer were carried out from 5 minutes to 15 minutes, with the results of 


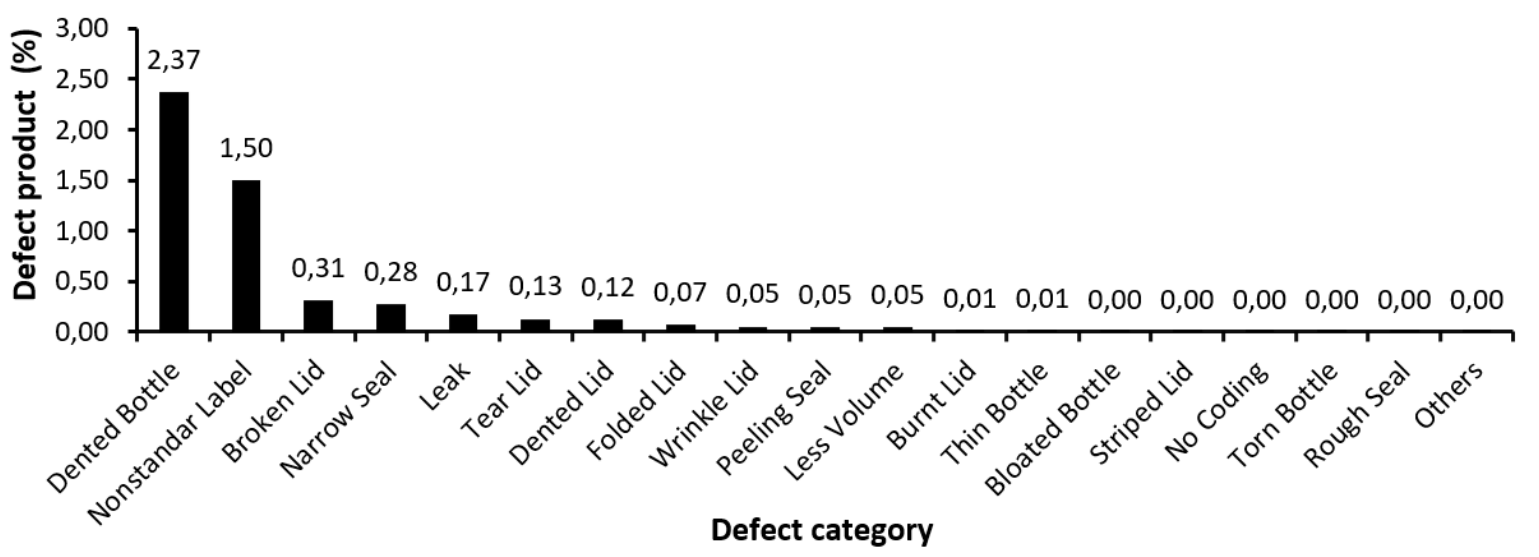

Figure 1: Pareto diagram of product defect categories during one year of production

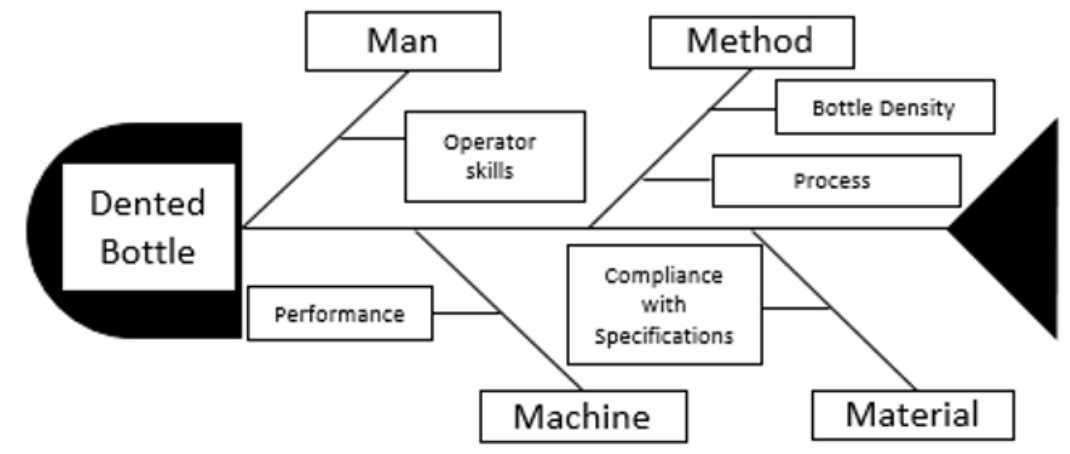

Figure 2: Fishbone diagram for the dented bottle defect category

correction at 10 minutes showing 1 second. This time correction is within the maximum correction limit required of 5 seconds. The pressure gauge calibration was carried out in the range of 1 bar to 4 bar. The correction value of the pressure gauge was +0.011 bar which is below the maximum correction of \pm 0.050 bar. The rotational speed of the basket was inspected at 800 to $1000 \mathrm{rpm}$. Correction for the rotational speed was $+5 \mathrm{rpm}$ which is lower than the maximum tolerable value of $\pm 10 \mathrm{rpm}$. The validation of the sterilization value results ranged from 10.41 - 13.29 minutes which meet the required minimum sterilization value of 10.00 minutes. Based on these annual inspection results it can be concluded that the over pressure rotary retort is in good condition and effectively performs the required sterilization process.

\section{Material}

Material factors observed in the fishbone diagram are specifications of bottles and lids. The bottle used is a single layer type HDPE, with a colorant agent. The HDPE material functions as a radiation barrier and oxygen barrier. Inspection of bottles was carried out by comparing the required and actual specifications. Based 
Reducing defective sterile milk products $\mid 225$

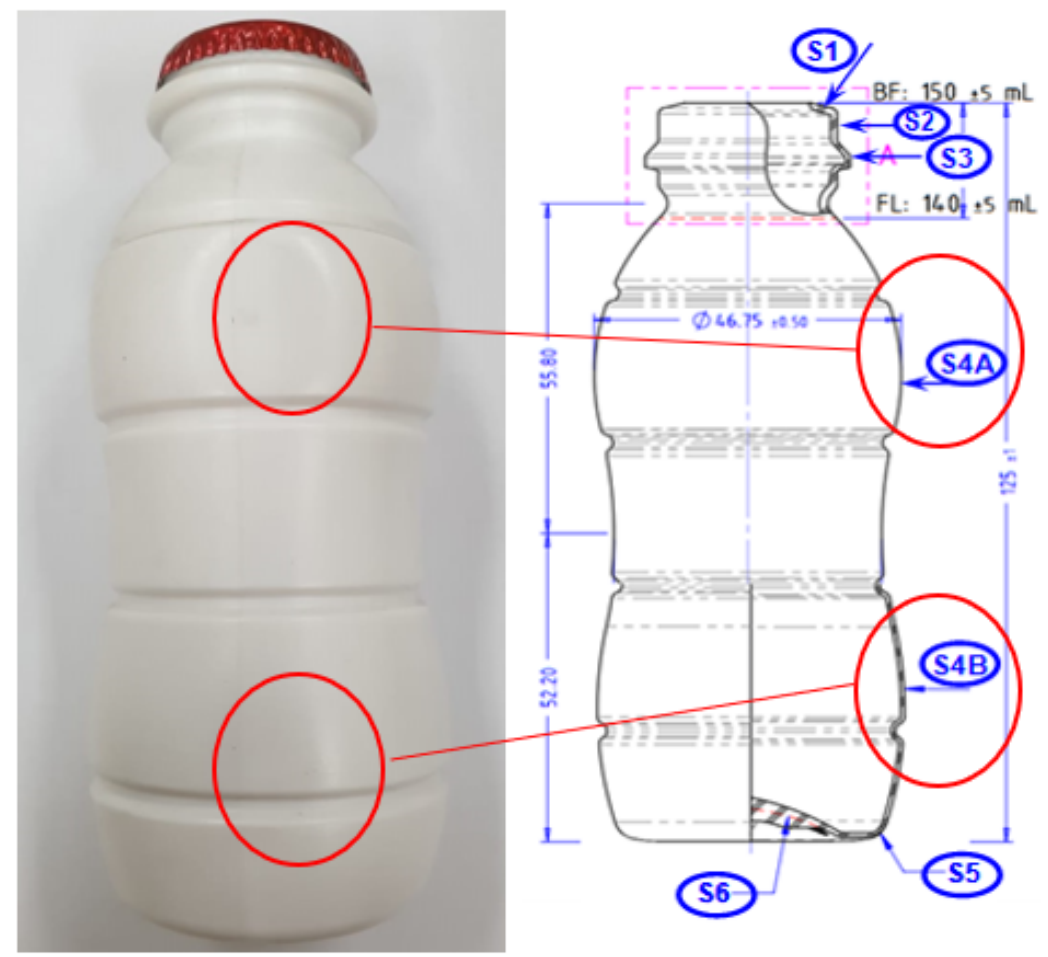

Figure 3: Position of dents in a defective bottle

Table 2: Physical properties of HDPE bottles (April 2019)

\begin{tabular}{lcccc}
\hline Parameters & Result & Standard & Unit & Note \\
\hline Glass Transition & 132.25 & $>130$ & ${ }^{o} \mathrm{C}$ & Pass \\
Wall thickness (S1) & 1.1 & $0.9-1.2$ & $\mathrm{~mm}$ & Pass \\
Wall thickness (S2) & 1.1 & $0.8-1.2$ & $\mathrm{~mm}$ & Pass \\
Wall thickness (S3) & 0.4 & $0.5-1$ & $\mathrm{~mm}$ & Pass \\
Wall thickness (S4A) & 0.6 & $0.35-0.8$ & $\mathrm{~mm}$ & Pass \\
Wall thickness (S4B) & 0.6 & $0.35-0.8$ & $\mathrm{~mm}$ & Pass \\
Wall thickness (S5) & 0.6 & $0.35-0.8$ & $\mathrm{~mm}$ & Pass \\
Wall thickness (S6) & 1.3 & $0.6-1.6$ & $\mathrm{~mm}$ & Pass \\
Sealing area & 3.4 & $2.5-3.5$ & $\mathrm{~mm}$ & Pass \\
$\mathrm{O}_{2}$ Transfer & 10.5 & $<11.0$ & $\times 1010 \mathrm{~cm}^{3} / \mathrm{cm}^{2} / \mathrm{mm} / \mathrm{sec} / \mathrm{cmHg}$ & Pass \\
$\mathrm{H}_{2} \mathrm{O}$ Transfer & 30.5 & $<32.0$ & $\times 1010 \mathrm{~cm}^{3} / \mathrm{cm}^{2} / \mathrm{mm} / \mathrm{sec} / \mathrm{cmHg}$ & Pass \\
\hline
\end{tabular}


Table 3: Cp and Cpk for bottle wall thickness parameters (S1-S6)

\begin{tabular}{lcc}
\hline Sampling point & Cp & Cpk \\
\hline S1 & 0.56 & 0.56 \\
S2 & 0.57 & 0.57 \\
S3 & 0.54 & 0.54 \\
S4A & 0.55 & 0.55 \\
S4B & 0.55 & 0.54 \\
S5 & 0.56 & 0.57 \\
S6 & 0.53 & 0.54 \\
\hline
\end{tabular}

on the results shown in Table 2 , it can be concluded that all the specified parameters were within the required standards. Release analysis is normally carried out for every bottle arrival once a year. The last release analysis was in April 2019. Plastic bottle thickness distribution and glass transition temperature are two possible packaging factors to cause dented bottles. Position of dents in a defective bottle after sterilization is shown in Figure 3. The thickness distribution is checked for every release and the glass transition temperature is checked annualy. The bottle thickness distribution, analyzed by Minitab 19, is shown in Table 3 and the bottles meet the specifications since $\mathrm{Cp}$ is equal to $\mathrm{Cpk}$, as also indicated in Figure 4 and Figure 5. $\mathrm{Cp}$ is an index of short-term process capability, where calculations only pay attention to the distribution of data but do not pay attention to data centering. Cpk is an index of short-term process capability, where calculations focus on the distribution and centering of data (Aslam, Wu, Azam \& Jun, 2013) It can be concluded that the material factor has no effect on a dented bottle.

The glass transition temperature of HDPE is $132.25^{\circ} \mathrm{C}$ which is much higher than the sterilization temperature of $121.0^{\circ} \mathrm{C}$. Therefore, the sterilization temperature is unlikely to cause dented bottles. Other possible factors that contribute to dented bottles are the packaging permeability and the structure of the bottle. Permeability of HDPE to $\mathrm{O}_{2}$ is $10.5 \times 10^{10} \mathrm{~cm}^{3} /$ $\mathrm{cm}^{2} / \mathrm{mm} / \mathrm{sec} / \mathrm{cmHg}$ and to $\mathrm{H}_{2} \mathrm{O}$ is $30.5 \times 1010$ $\mathrm{cm}^{3} / \mathrm{cm}^{2} / \mathrm{mm} / \mathrm{sec} / \mathrm{cmHg}$. These permeability values meet the standards as specified in Table
2.

Ring design contributes to strength of the bottle structure. The HDPE bottles used in this study have 4 circular rings, with a diameter of $2 \mathrm{~mm}$. The aluminium lid to seal the HDPE bottle has three different layers, i.e. aluminum, adhesive and LDPE. Table 3 indicates that all the lid parameters assessed are within the required standards and may not be the major cause of the dented bottle.

\section{Method}

Commercially sterilized milk is processed using a rotary over pressure retort. Process parameters which are important and may contribute to dented bottles are temperature, pressure and the percentage of the retort basket area occupied by bottles (bottle density). The temperature and pressure profiles during the sterilization process are shown in Figure 6. The maximum temperature experienced by products and the packaging material is $121.0^{\circ} \mathrm{C}$ which is much lower than the glass transition temperature as already discussed above. More importantly, a process parameter that potentially causes dents on the plastic bottle is pressure difference. Figure 6 shows that external pressure in the retort is 2.00 bar and the internal pressure in the bottle is 3.20 bar. An imbalance between external pressure and internal pressure may deform packaging, especially for packaging materials that cannot stand a high pressure difference. Hariyadi (2017) stated that there is excess pressure on over-pressure retorts which serves to keep the packaging from expanding too much and causing damage to the packaging. When the retort pressure is too low, the packaging expands because the internal pressure is higher than the external pressure. A pressure imbalance causes the product to expand and bottles to contact each other leading to dents. From focus group discussions it was agreed that pressure in the retort during the sterilization process is the main possible cause of dented HDPE bottles. A plan to reduce the pressure difference was developed for process improvement. Another possible cause of dented bottles from the method perspective is the percentage of the retort basket area occupied by bottles (bottle density). The bottle density used during normal production 
Reducing defective sterile milk products | 227

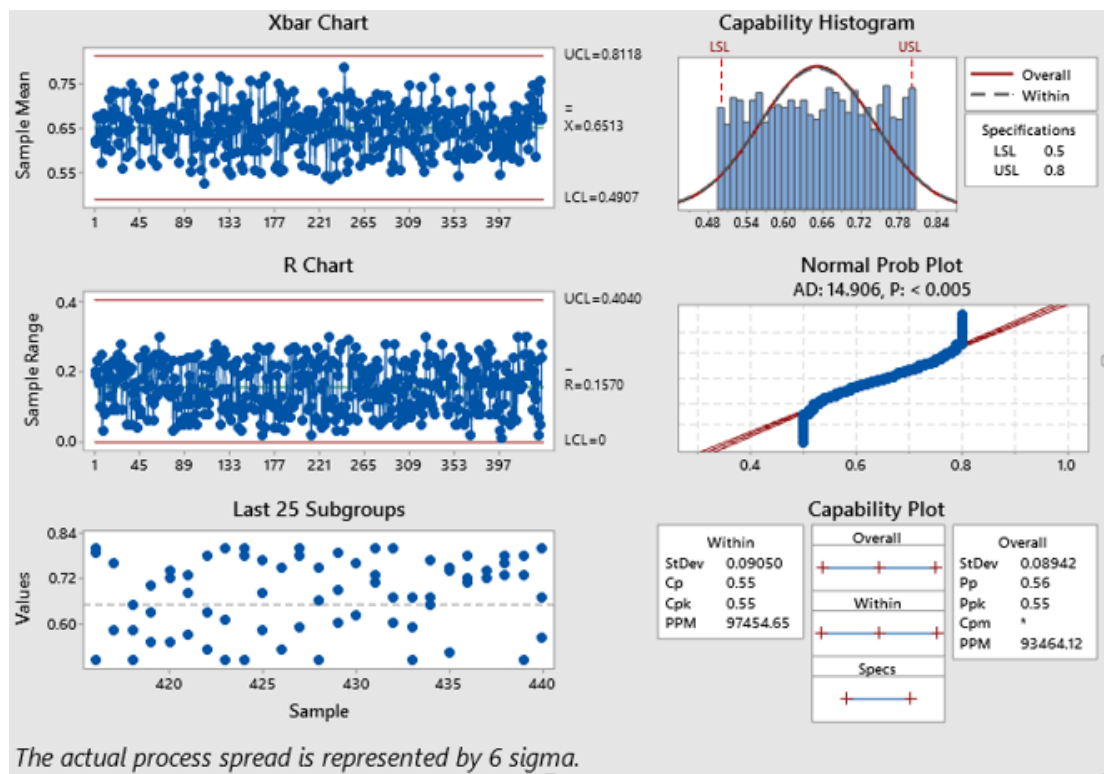

Figure 4: Control normal capability sixpack report on S4A for incoming bottles: March 2018-February 2019

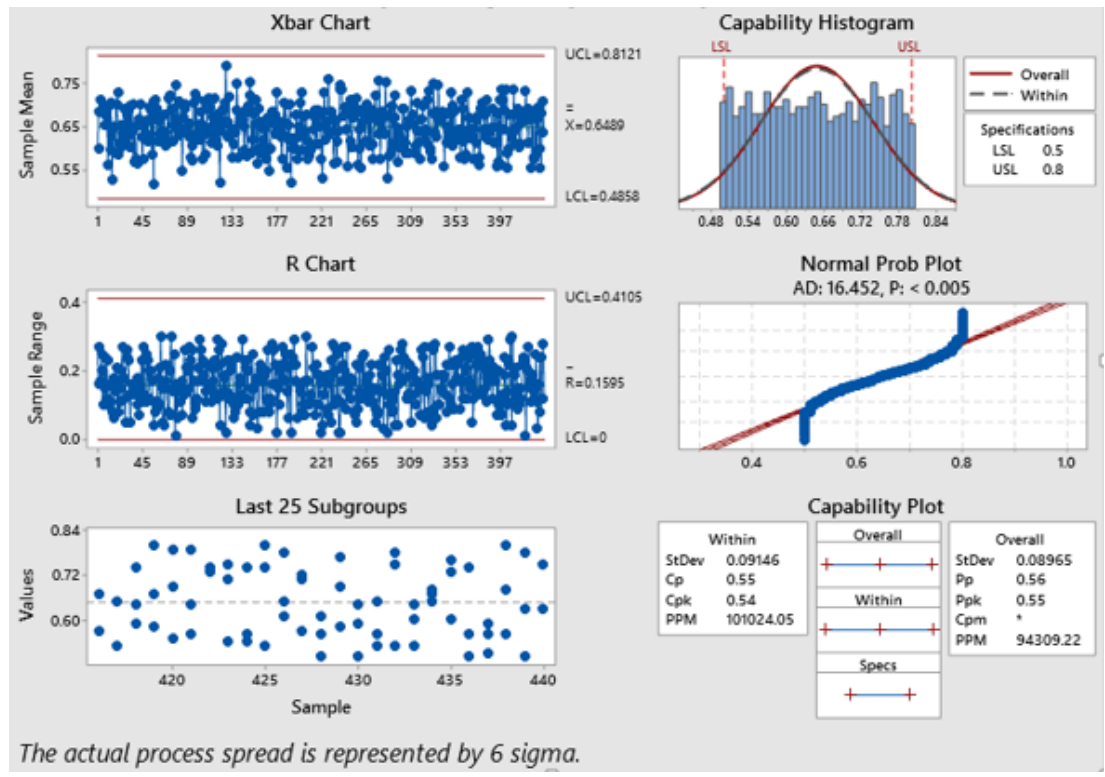

Figure 5: Control normal capability sixpack report on S4B for incoming bottles: March 2018-February 2019 


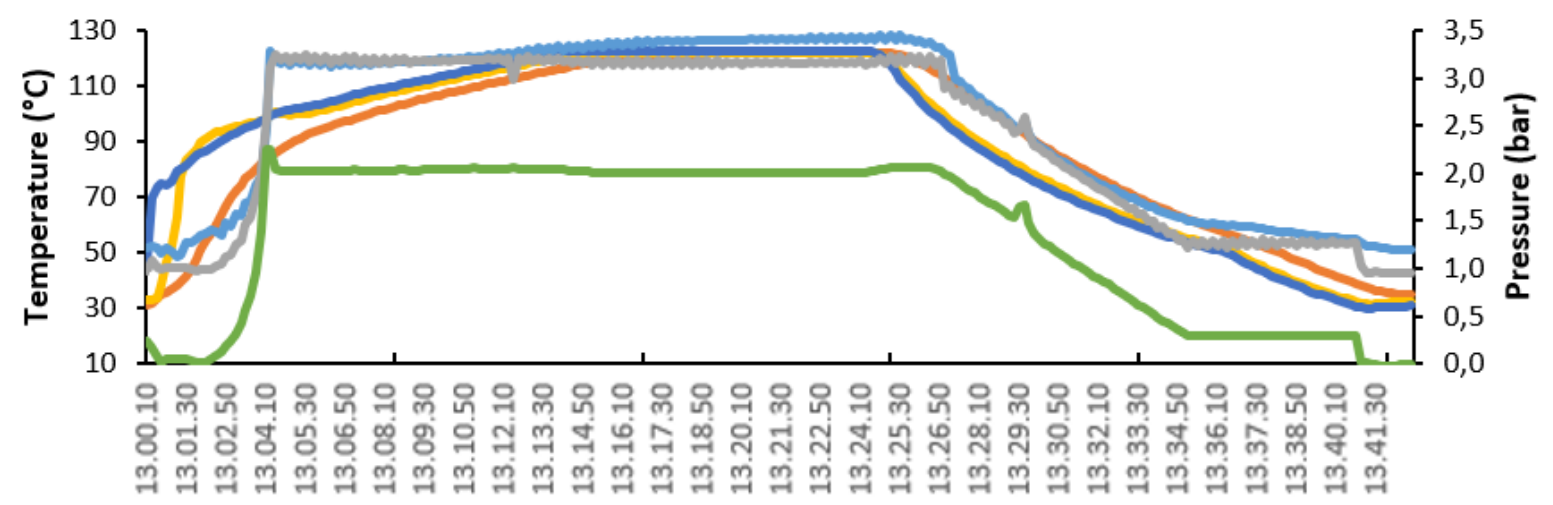

Time

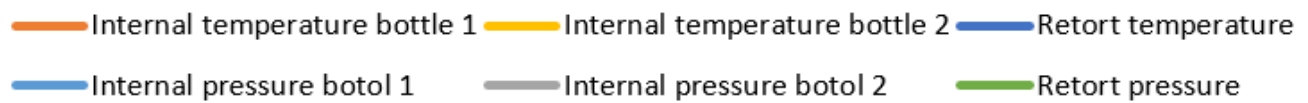

Figure 6: Chart of the sterilization process at retort sterilization temperature $121^{\circ} \mathrm{C}$, sterilization time 10 minutes, retort pressure 2.00 bar and $82 \%$ bottle density.

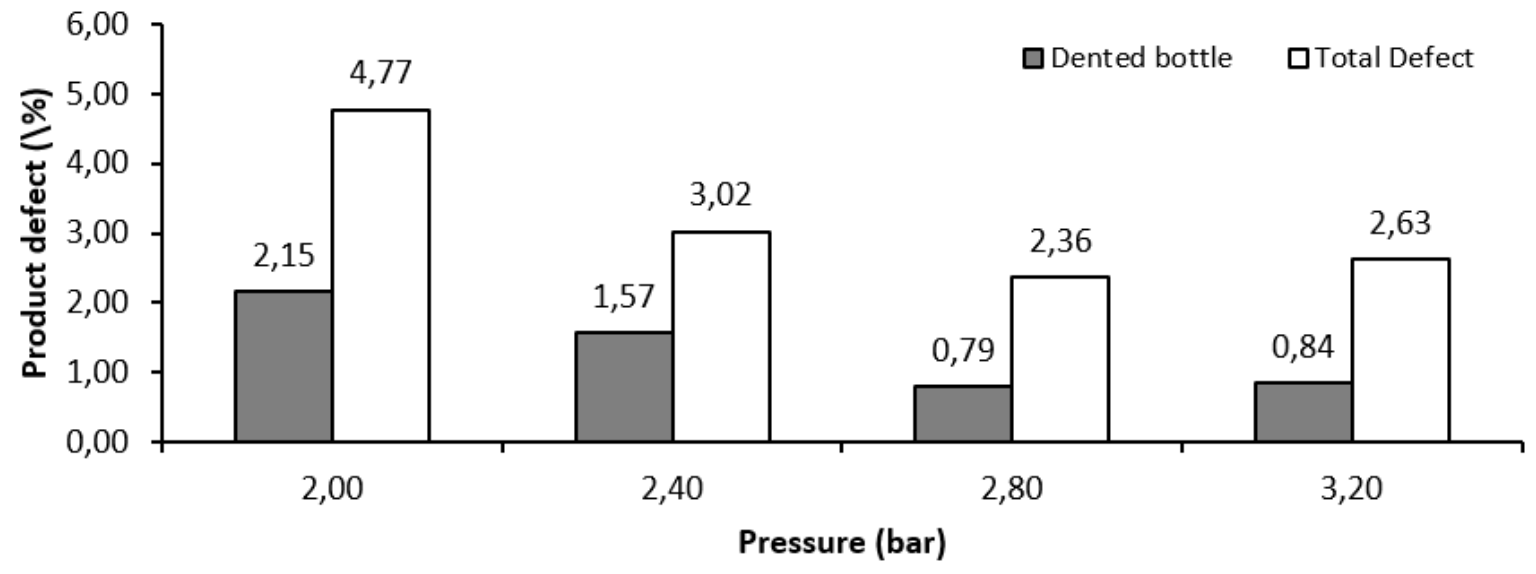

Figure 7: Percentage of product defects at various pressures, with retort sterilization temperature 121 ${ }^{\circ} \mathrm{C}$, sterilization time 10 minutes and $82 \%$ bottle density. 
Reducing defective sterile milk products $\mid 229$

Table 4: Physical properties of aluminium lids (April 2019)

\begin{tabular}{lcccc}
\hline Parameters & Result & Standard & Unit & Note \\
\hline External limitation & Conform & Conform & - & Pass \\
Width Tolerance & 116 & $114-118$ & $\mathrm{~mm}$ & Pass \\
Thickness Tolerance & 125 & $123-127$ & $\mu \mathrm{m}$ & Pass \\
Peel strength & 10.28 & $>3.5$ & $\mathrm{~N} / 15 \mathrm{~mm}$ & Pass \\
Heat sealing & 41.69 & $>440.00$ & $\mathrm{~N} / 15 \mathrm{~mm}$ & Pass \\
Sterilization at $121{ }^{\circ} \mathrm{C}(30 \mathrm{~min})$ & Conform & Conform & - & Pass \\
\hline
\end{tabular}

routine is $82 \%$. For futher improvement, experiments were carried out by reducing the bottle density from $82 \%$ to $77 \%$ and $73 \%$ at optimum retort pressure.

\subsection{Improvement of the Largest Defect Category}

The improvement plan to reduce dented bottle defects was executed by increasing retort pressure from 2.00 bar to 2.40 bar, 2.80 bar and 3.20 bar. The experimental results are shown in Figure 7, where an increasing pressure decreased the percentage of dented bottle. A better balance between internal and external pressure in the bottle reduces the number of dented bottles. Least dented bottles was obtained at a retort pressure of 2.80 bar, where $2.36 \%$ of all products produced were defective and $0.79 \%$ of all products were dented bottle defects. Based on this result, the retort pressure used in studying the effect of bottle density was 2.80 bar.

Reducing the number of defective HDPE bottles by increasing the retort pressure may affect the sterility level received by the products. Therefore, it was necessary to measure the sterility level $\left(\mathrm{F}_{0}\right.$ value $)$ by performing a heat penetration test using 12 data loggers. $F_{0}$ values were calculated using a trapezoidal method, with a $\mathrm{z}$ value of $10{ }^{\circ} \mathrm{C}$ based on Clostridium botulinum (Membre \& van Zuijlen, 2010). Minimum $\mathrm{F}_{0}$ and maximum $\mathrm{F}_{0}$ results, and their difference, are shown in Figure 8. All $\mathrm{F}_{0}$ values were greater than 10 minutes which indicates that the sterilization process was sufficient.

The bottle density is the percentage of the retort basket area $(6,496 \mathrm{~cm} 2)$ occupied by bottles.
A reduction in bottle density from $82 \%$ to $77 \%$ and $73 \%$ was expected to provide the right distance for bottles to expand. Based on the results shown in Figure 9, it can be concluded that reducing bottle density reduces total defects and dented bottles. However, there was an increase in striped lid defects caused by friction between the aluminum lid and spacer mat due to loose space when the basket rotates, and a reduction in productivity. Therefore, this strategy to reduce bottle density was considered ineffective as a solution for reducing product defects.

\subsection{Verification of Improvement Results}

According to Giwa et al. (2019), experiment results obtained on a process over a short-term period of time need to be verified over a longterm period of time. Studying the process over a long-term $\mathrm{p}$ period of time can accommodate other factors that did not appear during the short-term study of the process. The results of the long-term study over a threemonth period, where $3,495,726$ bottles were produced, are shown in Figure $10.2 .24 \%$ of all products sterlized were defective and $0.76 \%$ of all products were dented bottle defects. These results are comparable with those obtained during the production trial at 2.80 bar $(2.63 \%$ of all products defective and $0.79 \%$ dented bottle defects). Therefore, it can be concluded that an increased retort pressure to maintain pressure balance in the HDPE bottles can result in a reduced number of dented bottle defects during the company's routine production. By applying a retort pressure of 2.80 bars can reduce the percentage of

\begin{tabular}{l|l|l|l} 
IJFS & April 2021 & Volume 10 & pages 221-232
\end{tabular} 


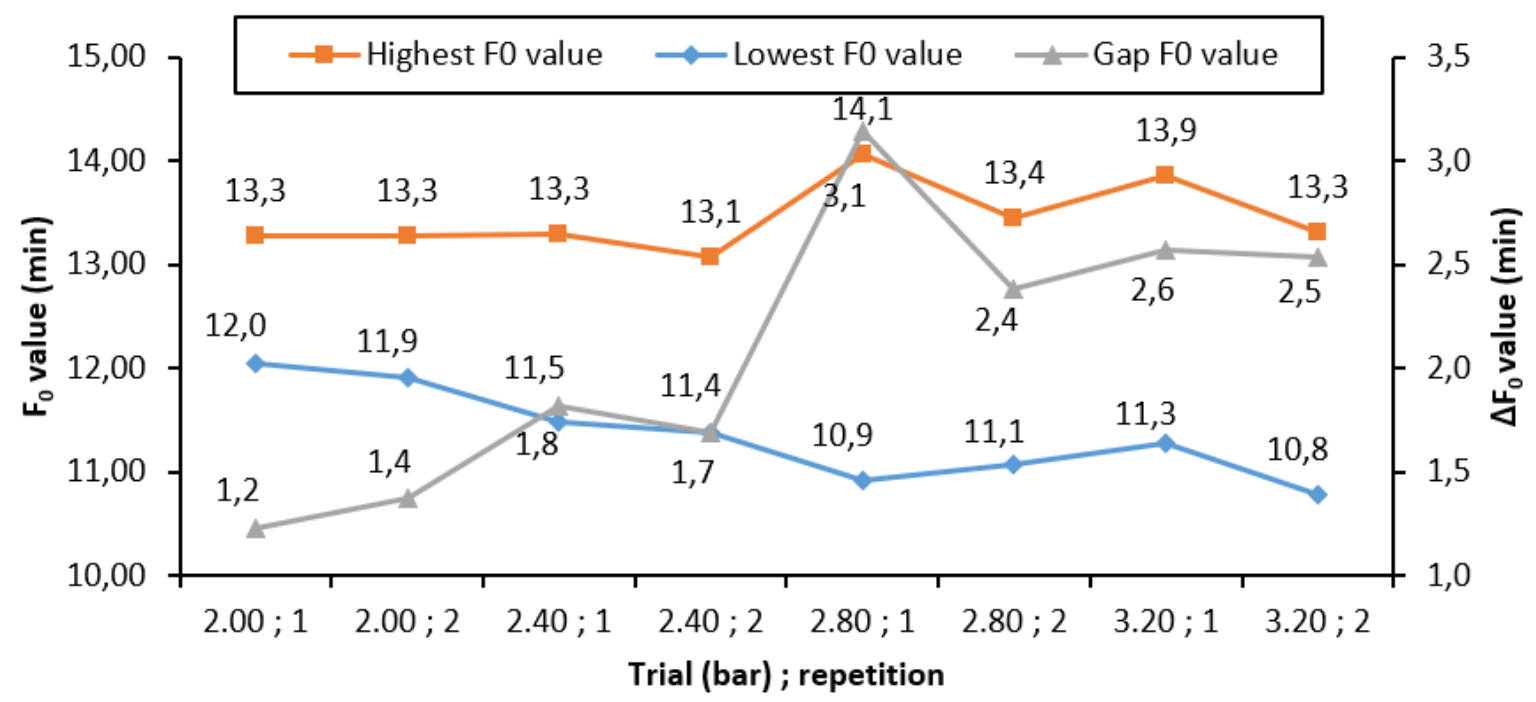

Figure 8: Sterilizing values $\left(\mathrm{F}_{0}\right)$ at various pressures, with retort sterilization temperature $121{ }^{\circ} \mathrm{C}$, sterilization time 10 minutes, and $82 \%$ bottle density.

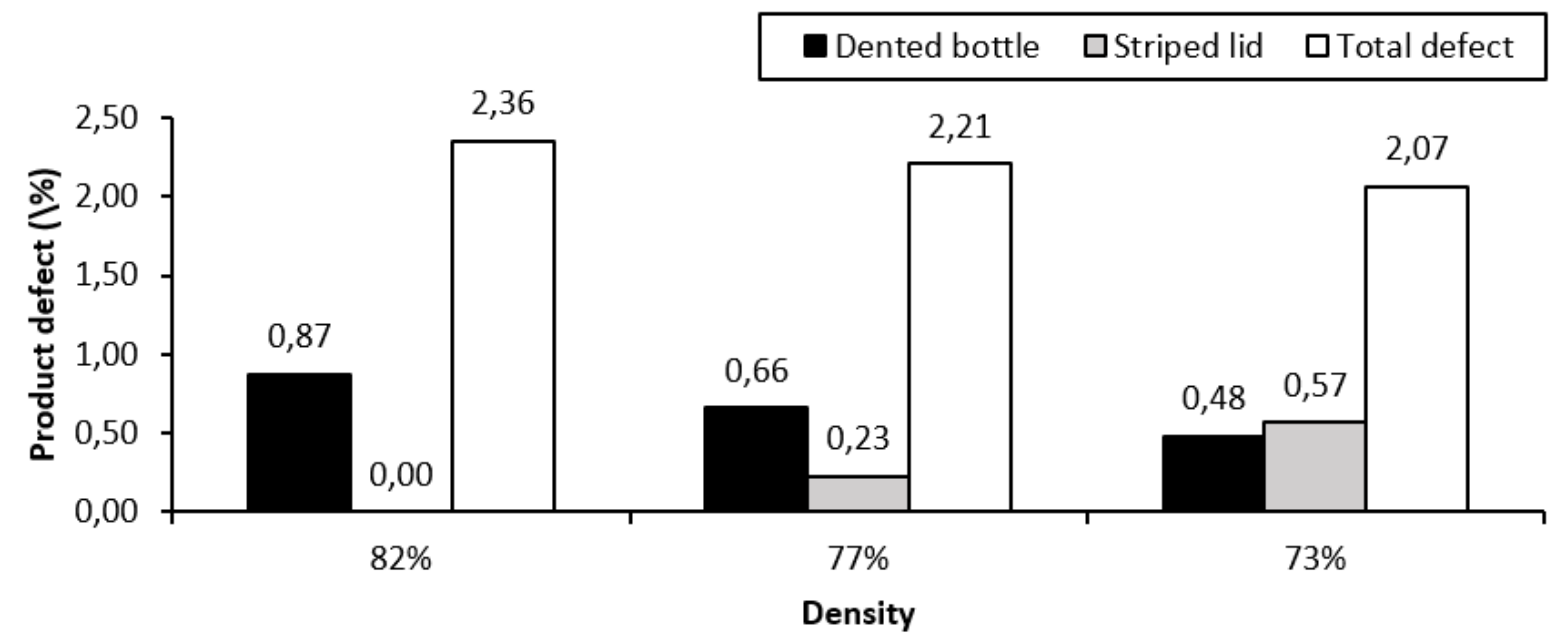

Figure 9: Percentage of product defects at various bottle densities, with retort pressure 2.80 bar, sterilization temperature $121^{\circ} \mathrm{C}$ and sterilization time 10 minutes. 


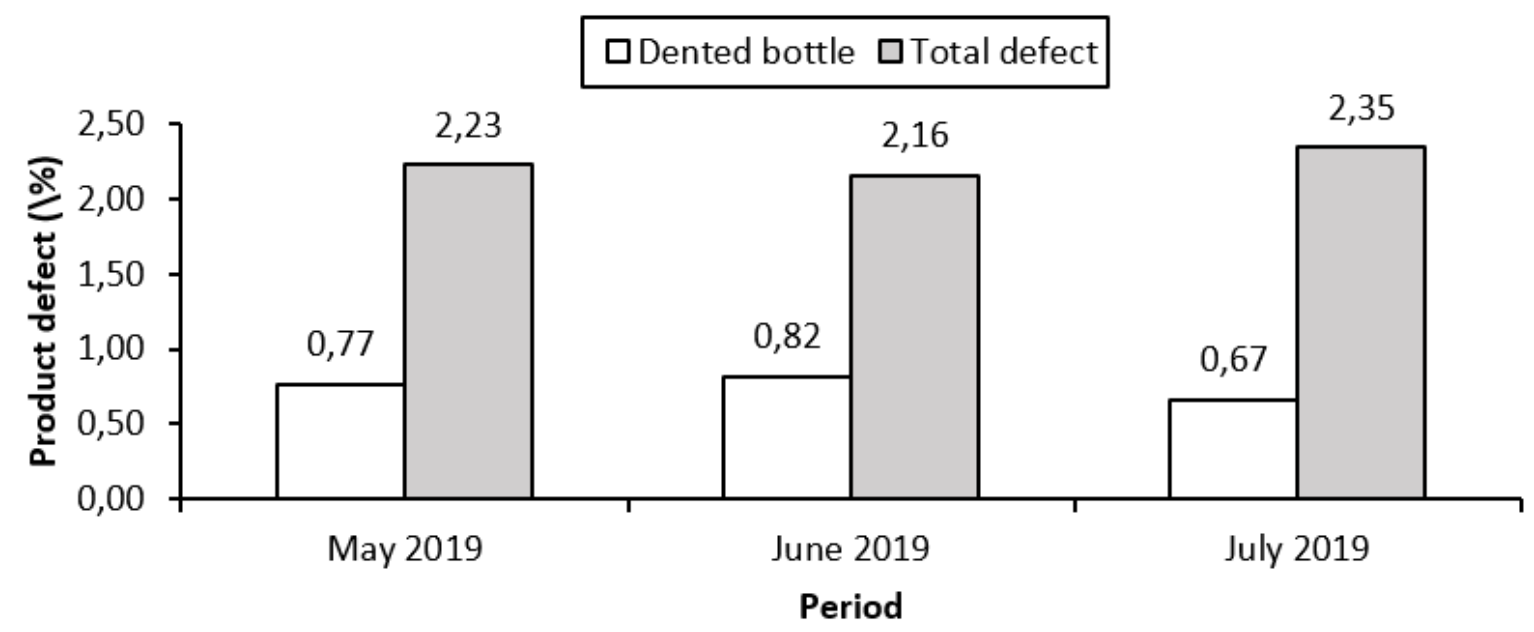

Figure 10: Percentage of product defects during three-month production, with retort pressure 2.80 bar, sterilization temperature $121^{\circ} \mathrm{C}$, sterilization time 10 minutes and $82 \%$ bottle density.

defective products produced by the company by $2.9 \%$. Based on the monthly production volume, the company gains an additional output of 73,080 bottles which is equivalent to USD 16,733 per month.

\section{Conclusion}

Production of commercially sterilized millk in HDPE bottles experienced product loss, where $5.14 \%$ of all products produced were defective and $2.37 \%$ of all products were dented bottle defects. Dented HDPE bottles was the largest defect category based on Pareto analysis. Based on the cause-effect diagram, the root cause of the dented bottles was a pressure imbalance experienced by the bottles during the sterilization process. The retort pressure was 2.00 bar, while the internal pressure was 3.20 bar. These conditions cause the product to expand and bottles to contact each other leading to dents. Production trials carried out at a retort pressure of 2.80 bar improved the process, where $2.36 \%$ of all products produced were defective and $0.79 \%$ of all products were dented bottle defects. Applying a lower bottle density during the sterilization process could decrease the number of dented bottles, however, it increased the num- ber of striped lid defects and reduced productivity. The best conditions for sterilization (retort pressure $=2.80$ bar; number of bottles/baskets $=1938$ bottles) were verified over a three-month full-scale production trial. By applying a retort pressure at 2.80 bar the percentage of defective products could be reduced by $2.9 \%$, and in return this could save the company up to 73,080 bottles monthly (equivalent to USD 16,733).

\section{References}

Ahmad, S. \& Ginantaka, A. (2018). Pengaruh perlakuan fisik dan variasi produk second grade terhadap kebocoran dan sifat fisik pada produk industri susu dalam kemasan botol. Jurnal Agroindustri Halal, 4 (1), 10 21. Retrieved from https://ojs.unida.ac. id/Agrohalal/article/view/010-021

Aslam, M., Wu, C.-W., Azam, M. \& Jun, C.-H. (2013). Variable sampling inspection for resubmitted lots based on process capability index Cpk for normally distributed items. Applied Mathematical Modelling, 37(3), 667-675.

Augusto, P. E. D., Tribst, A. A. L. \& Cristianini, M. (2014). THERMAL PROCESSES Commercial Sterility (Retort). In C. A. 
Batt \& M. L. Tortorello (Eds.), Encyclopedia of food microbiology (second edition) (Second Edition, pp. 567-576). doi:10 . 1016/B978-0-12-384730-0.00405-5

Elleuch, H., Dafaoui, E., El Mhamedi, A. \& Chabchoub, H. (2016). A quality function deployment approach for production resilience improvement in supply chain: Case of agrifood industry. IFAC Papersonline, 49(31), 125-130. 12th IFAC Workshop on Intelligent Manufacturing Systems (IMS), Austin, TX, DEC 05-07, 2016. doi:10.1016/ j.ifacol.2016.12.173

Erdil, A. (2019). An evaluation on lifecycle of products in textile industry of turkey through quality function deployment and pareto analysis. Procedia Computer Science, 158, 735-744. doi:10.1016/j.procs. 2019.09.109

Giwa, A. S., Xu, H., Chang, F., Wu, J., Li, Y., Ali, N., ... Wang, K. (2019). Effect of biochar on reactor performance and methane generation during the anaerobic digestion of food waste treatment at longrun operations. Journal of Environmental Chemical Engineering, 7(4). doi:10.1016/j. jece.2019.103067

Hariyadi, P. (2017). Teknologi proses termal untuk industri pangan. Media Pangan Indonesia Bogor.

Kong, D., Yang, X. \& Xu, J. (2019). Energy price and cost induced innovation: Evidence from china. Energy, 192. doi:10.1016/ j.energy.2019.116586

Magnusson, T. \& Berggren, C. (2017). Competing innovation systems and the need for redeployment in sustainability transitions. Technological Forecasting and Social Change, 126, 217-230. doi:10.1016/j. techfore.2017.08.014

Membre, J.-M. \& van Zuijlen, A. (2010). A probabilistic approach to determine thermal process setting parameters: Application for commercial sterility of products. International Journal of Food Microbiology, 144(3), 413-420. doi:10.1016/ j . ijfoodmicro.2010.10.028

Potts, H. L., Amin, K. N. \& Duncan, S. E. (2017). Retail lighting and packaging influence consumer acceptance of fluid milk.
Journal of Dairy Science, 100(1), 146-156. doi:10.3168/jds.2016-11673

Primanintyo, B., Syafei, M. Y. \& Luviyanti, D. (2016). Analisis penurunan jumlah defect dalam proses tire-curing dengan penerapan konsep six sigma. Journal of Industrial Engineering, 1(2).

Shivajee, V., Singh, R. K. \& Rastogi, S. (2019). Manufacturing conversion cost reduction using quality control tools and digitization of real-time data. Journal of Cleaner Production, 23\%. doi:10.1016/j.jclepro. 2019. 117678

Simanova, L. \& Gejdos, P. (2015). The use of statistical quality control tools to quality improving in the furniture business. In A. Sujova \& L. Krajcirova (Eds.), International scientific conference: Business economics and management (bem2015) (Vol. 34, pp. 276-283). Procedia Economics and Finance. 9th International Scientific Conference on Business Economics and Management (BEM), Tech Univ Zvolen, Izmir, TURKEY, APR 30-MAY 02, 2015. Wood Congress; Tech Univ Zvolen, Dept Business Econ. doi:10 . 1016 / S2212 5671(15)01630-5

Wang, S. Y. \& Choi, S. H. (2019). Pareto-efficient coordination of the contract-based mto supply chain under flexible cap-and-trade emission constraint. Journal of Cleaner Production, 250. doi:10.1016/j . jclepro . 2019.119571

Wulandari, I. \& Bernik, M. (2018). Penerapan metode pengendalian kualitas six sigma pada heyjacker company. EkBis: Jurnal Ekonomi dan Bisnis, 1(2), 222-241.

Zhang, X., Kano, M., Tani, M., Mori, J. \& Harada, K. (2018). Defect data modeling and analysis for improving product quality and productivity in steel industry. In Computer aided chemical engineering (Vol. 44, pp. 2233-2238). Elsevier.

Zheng, X., Zhang, X., Ma, L., Wang, W. \& $\mathrm{Yu}$, J. (2019). Mechanical characterization notched high density polyethylene (hdpe) pipe: Testing and prediction. International Journal of Pressure Vessels and Piping, 173, 11-19. doi:10.1016/j.ijpvp.2019.04.016 